\title{
Inhibitory effect of alcohol on ghrelin secretion in normal man
}

\author{
Jan Calissendorff, Olle Danielsson ${ }^{1}$, Kerstin Brismar and Sven Röjdmark ${ }^{2}$ \\ Department of Endocrinology, Metabolism and Diabetology and ${ }^{1}$ Department of Clinical Chemistry, Karolinska University Hospital, 17176 Stockholm, \\ Sweden and ${ }^{2}$ Department of Medicine, Section of Endocrinology, Stockholm Söder Hospital, Stockholm, Sweden \\ (Correspondence should be addressed to J Calissendorff; Email: jan.calissendorff@karolinska.se)
}

\begin{abstract}
Background: Human appetite is stimulated by alcohol but the underlying mechanism is unknown. It is possible that hunger-stimulating hormones are mediators of this effect of alcohol. Ghrelin stimulates hunger, but how alcohol affects human ghrelin secretion has never been studied before.

Objective: To investigate whether alcohol ingestion exerts an acute influence on serum ghrelin concentrations in healthy subjects.

Subjects and design: Eight healthy non-obese subjects participated in the study. All were investigated on two occasions (experiments $\mathrm{A}$ and $\mathrm{B})$. Alcohol ( $0.55 \mathrm{~g}$ ethanol $/ \mathrm{kg}$ body weight) was ingested in experiment A, and drinking-water in experiment B. Venous blood was collected before, and 30 and $60 \mathrm{~min}$ after consumption of the drinks. Serum concentrations of ghrelin, cortisol and ethanol were determined and neuropeptide Y (NPY) concentrations were determined in plasma.

Results: Alcohol lowered the ghrelin level by $13.9 \pm 5.0 \%$ at $30 \mathrm{~min}$ and by $17.5 \pm 2.6 \%$ at $60 \mathrm{~min}$, in contrast to drinking-water which was without significant effect. Serum levels of cortisol and insulin were similar after alcohol and water as was plasma NPY.

Conclusion: Alcohol has an acute inhibitory influence on human ghrelin secretion but no measurable effect on the secretion of NPY and cortisol. Hence, none of these hormones mediate the orexigenic effect of the drug.
\end{abstract}

European Journal of Endocrinology 152 743-747

\section{Introduction}

It is well known that alcohol ingestion may serve as an appetizer causing increased food intake in both normal weight $(1,2)$ and obese (2) individuals. The mechanism underlying this effect is unclear, but it is known that alcohol, besides suppressing fatty acid oxidation and increasing short term thermogenesis, may also affect neurochemical systems involved in the control of appetite (3). Hormone systems may also be involved, since both hunger and satiety are to a great extent regulated by such systems within the central nervous system $(4,5)$. Hypothalamic neuropeptide Y (NPY) plays a key role in this context, since it has a strong stimulatory influence on hunger $(6,7)$. Leptin may also be of importance. This adipocyte-derived hormone affects hunger signals indirectly by inhibiting NPY $(5,8)$. Other hormones may, in turn, influence leptin. This applies to insulin and cortisol which increase leptin secretion $(9,10)$, whereas testosterone and catecholamines have the opposite effect $(11,12)$. Considering these previous findings it is reasonable to assume that one or several of the above mentioned hormones, acting alone or in concert, could mediate the appetite-stimulating effect of alcohol.
We have focused on this issue in our recent investigations and have noted that acute ingestion of moderate amounts of alcohol inhibits leptin secretion significantly (13), but leaves circulating glucose concentrations (13, 14) and the secretion of insulin (13, 14), cortisol (13), catecholamines (15) and testosterone (13) unaffected. Although the leptin decline after alcohol ingestion suggests that leptin could be the appetite-stimulating factor we are looking for, this cannot be taken for granted, since leptin is known for long-term rather than short-term effects on food consumption and caloric homeostasis $(16,17)$. In order to find other plausible mechanisms underlying the short-term appetite-stimulating effect of alcohol, additional factors should be considered. One such factor is ghrelin. Ghrelin is predominantly produced in the mucose membrane of the upper gastrointestinal tract (18) and it stimulates the production of NPY (19). How alcohol affects human ghrelin secretion has not been studied before. Therefore, the objective of the present investigation was to study whether intake of a moderate amount of alcohol exerts an acute influence on serum levels of ghrelin in healthy subjects. 


\section{Subjects and methods}

\section{Subjects}

Eight healthy volunteers were included in the investigation. Four were women aged $25 \pm 4$ years and four were men $21 \pm 2$ years old. Their body mass indices were $21 \pm 2$ and $23 \pm 1 \mathrm{~kg} / \mathrm{m}^{2}$ respectively. All were free of medication. They used moderate amounts of alcohol at social events, but none was addicted to liquor, and all refrained completely from using alcohol in any form during the 3 days prior to the experiments. They were informed of the purpose of the study and gave their voluntary consent to participate. The investigation was approved by the ethics committee at the Karolinska University Hospital in Stockholm.

\section{Protocol}

Each individual took part in two experiments (A and B), which were performed in a metabolic ward, in random order, and 1-2 weeks apart.

Experiment $\boldsymbol{A}$ At $0730 \mathrm{~h}$ a catheter was inserted into one of the antecubital veins which was kept patent by a slow drip of normal saline. After an equilibration period of $30 \mathrm{~min}$, basal blood samples were collected from the catheter. Then, alcohol was given orally at a dose of $0.55 \mathrm{~g}$ ethanol $/ \mathrm{kg}$ body weight (combustion of $1 \mathrm{~g}$ ethanol yields $6.9 \mathrm{kcal}$ ). Blood samples for determination of serum ghrelin, cortisol and plasma NPY were taken immediately before the alcohol ingestion (at $0800 \mathrm{~h}$ ), and subsequently at 0830 and $0900 \mathrm{~h}$. Serum ethanol concentrations were measured at 0800 and $0900 \mathrm{~h}$.

Experiment B In this experiment drinking-water was substituted for alcohol. In all other details experiments $\mathrm{A}$ and $\mathrm{B}$ were identical.

\section{Assays}

After collection, serum and plasma samples were stored deeply frozen $\left(-20^{\circ} \mathrm{C}\right)$ until analysed $5-7$ weeks later. Means of duplicate determinations were used. All analyses in one single individual were included in the same assay.

Total serum ghrelin concentrations were measured by RIA (Ghrelin (total) RIA kit, Linco Research, St Charles, MO, USA). The sensitivity of the assay was $100 \mathrm{pg} / \mathrm{ml}$, and the intra- and interassay coefficients of variation were $4.4 \%$ and $16.7 \%$ respectively at serum ghrelin concentrations of approximately $3000 \mathrm{pg} / \mathrm{ml}$.

Plasma NPY levels were also measured by use of an RIA technique (20). The sensitivity of the assay was $1.9 \mathrm{pmol} / \mathrm{l}$ and the intra- and interassay coefficients of variation were $7.2 \%$ and $9.3 \%$ respectively at plasma concentrations of $43 \mathrm{pmol} / \mathrm{l}$.
Serum cortisol levels were determined by fluorescence immunoassay (autoDELFIA, Wallac Oy, Turku, Finland). Intra- and interassay coefficients of variation were $4.9 \%$ and $6.4 \%$ respectively at serum concentrations of $157 \mathrm{nmol} / \mathrm{l}$.

An automated Hitachi 911 analyser from Roche Diagnostics, Bromma, Sweden made it possible to measure serum ethanol levels.

\section{Statistical analysis}

Difference over time with treatments, between treatments, and interaction between time and treatment, were analysed by two-way repeated measures ANOVA and, if significant, followed by Newman-Keuls' posthoc test. $P$ values $<0.05$ were considered significant. Values are shown as means \pm s.E.M. Data processing was performed using Statistica, Statsoft version 6.1 (Tulsa, OK, USA).

\section{Results}

\section{Serum ethanol}

After ingestion of alcohol (experiment A) the ethanol concentration rose from zero to $19.0 \pm 0.6 \mathrm{mmol} / \mathrm{l}$ in $60 \mathrm{~min}$ $(P<0.001)$. In experiment $\mathrm{B}$ the ethanol concentration remained at zero throughout the study (Fig. 1).

\section{Serum ghrelin}

In experiment $A$, the basal ghrelin level was $2662 \pm 165 \mathrm{pg} / \mathrm{ml}$. It fell by $13.9 \pm 5.0 \%$ to $2274 \pm 172 \mathrm{pg} / \mathrm{ml} 30 \mathrm{~min}$ after ingestion of alcohol $(P<0.02)$ and by $17.5 \pm 2.6 \%$ to $2178 \pm 110 \mathrm{pg} / \mathrm{ml}$ after $60 \mathrm{~min}(P<0.002)$. In experiment $\mathrm{B}$, the basal ghrelin concentration was $2611 \pm 194 \mathrm{pg} / \mathrm{ml}$. This was not significantly different from the corresponding basal level in experiment A. It was $2649 \pm 188 \mathrm{pg} / \mathrm{ml}$ $30 \mathrm{~min}$ after ingestion of water, and $2606 \pm 166 \mathrm{pg} / \mathrm{ml}$ after $60 \mathrm{~min}$. These levels were not significantly different from the basal level. When comparing the ghrelin concentrations after the ingestion of alcohol or water significant differencies were obtained $(P<0.02$ at $30 \mathrm{~min}$, and $P<0.01$ at $60 \mathrm{~min}$ ) (Fig. 1).

\section{Plasma NPY}

Basal plasma NPY levels were similar in experiments A and $\mathrm{B}(18.6 \pm 2.0$ and $16.1 \pm 1.9 \mathrm{pmol} / \mathrm{l}$ respectively (not significantly different, NS)). The levels did not change significantly after alcohol or water (Fig. 1).

\section{Serum cortisol}

Basal cortisol levels were $401 \pm 31$ and $420 \pm 18 \mathrm{nmol} / \mathrm{l}$ in experiments A and B respectively (NS). Cortisol levels declined both significantly $(P<0.001$ at both 30 and 

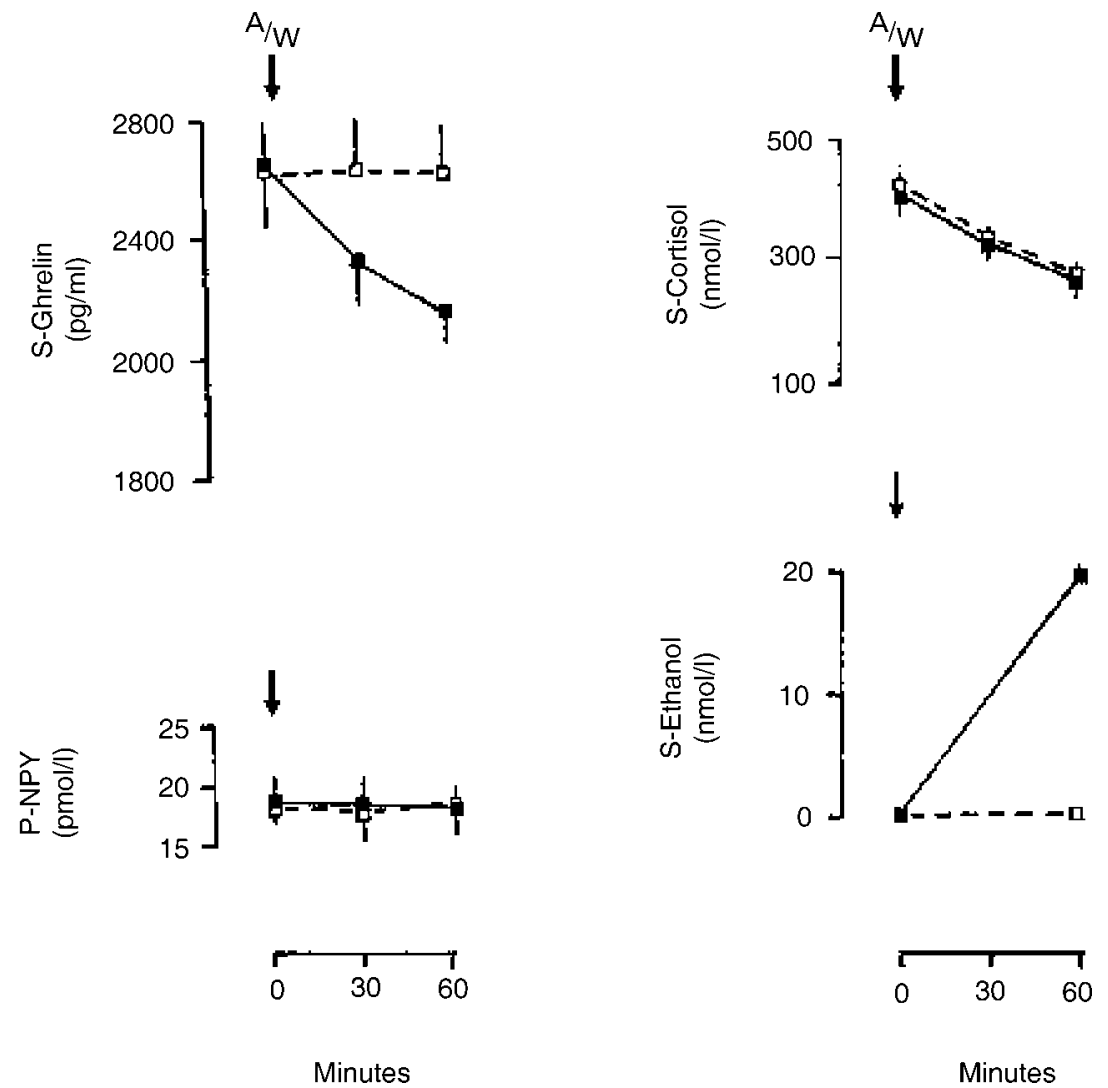

$60 \mathrm{~min}$ ) and similarly after alcohol and water as shown in Fig. 1.

\section{Discussion}

In this investigation alcohol inhibited ghrelin secretion acutely in contrast to drinking-water which was without significant influence. The ghrelin inhibition could either be a direct effect of alcohol on ghrelin-producing cells in the stomach, or an indirect influence mediated by other factors. Leptin is one such factor. It is inhibited by acute ingestion of alcohol (13). If leptin stimulates the secretion of ghrelin an alcohol-induced ghrelin decline would probably ensue. However, leptin has not been found to stimulate human ghrelin secretion. Instead, Chan et al. have shown that endogenous serum levels of leptin and ghrelin are inversely correlated (21). Furthermore, both physiological and pharmacological doses of recombinant leptin fail to affect human ghrelin secretion (21).

Cortisol may also be excluded from the list of possible mediators of the alcohol effect. This is because we found serum levels of cortisol in the current study which were almost identical after ingestion of alcohol or drinkingwater.

The dose of alcohol given to our participants was $0.55 \mathrm{~g} / \mathrm{kg}$ body weight. This dose is equivalent to $10 \mathrm{cl}$ whisky and yields $266 \mathrm{kcal}$ in a $70 \mathrm{~kg}$ man. It could be argued that it is this caloric provision, rather than the ethanol solution per se, that inhibits the secretion of ghrelin. However, if the recent findings of Nedvidkova and colleagues are taken into account this hypothesis also appears to be unlikely. They found that the plasma ghrelin response to food intake was independent of meal caloric value in healthy subjects (22)

Although alcohol may affect ghrelin secretion via changed NPY production, findings presented in this study do not favour such a notion inasmuch as plasma NPY levels remained unchanged after ingestion of both alcohol and water. However, an unchanged NPY level after alcohol does not unequivocally exclude NPY from being a mediator of the alcohol effect on ghrelin. Small changes in the production of NPY may be difficult to discern by measuring NPY concentrations in peripheral blood, due to the fact that centrally produced NPY has to traverse the blood-brain barrier before being considerably diluted in the systemic circulation.

Glucagon-like peptide 1 (GLP-1), gastrin-releasing peptide (GRP), cholecystokinin (CCK) and peptide YY (PYY) are hormones which are involved in the regulation of food intake (23-28). Hence, all of them are possible mediators of alcohol. They are all secreted by endocrine cells in the gastrointestinal tract. GLP-1, GRP and CCK inhibit gastric emptying partly by 
conveying afferent vagal satiety signals to the brain (25). It has been reported that the vagal system may play an important role in the control of ghrelin secretion $(29,30)$. If so, it is possible that alcohol decreases ghrelin secretion via vaso-vagal reflexes. Raben et al. recently observed that alcohol does not influence the secretion of human GLP-1 (31). Whether alcohol stimulates hunger by influencing the secretion of GRP, CCK or PYY is unknown and has to be given closer attention in future studies.

Multiple ulcers arise in rats when their gastric mucosa is exposed to ethanol $(32,33)$. This makes it reasonable to assume that alcohol may have a toxic effect on ghrelin-secretory cells in the stomach, resulting in decreased hormone secretion. However, findings in rats, recently presented by Konturek et al., are at variance with such an assumption. These authors found not only that the mucosal expression of ghrelin is enhanced in rats after exposure to ethanol, but also that ghrelin exhibits strong gastroprotection in these animals (33). Why ghrelin responsiveness to ethanol appears to differ between humans and rats is not readily apparent, but species differences, different alcohol doses, or differences in the length of alcohol exposure are plausible explanations which merit additional investigation.

In conclusion, alcohol has an acute inhibitory influence on ghrelin secretion but has no significant effect on NPY and cortisol. When it is taken into account that alcohol both stimulates appetite and inhibits appetite-stimulating ghrelin secretion, it may be concluded that ghrelin is not a hormone which mediates the orexigenic effect of alcohol.

\section{Acknowledgements}

This study has been supported by funds from Capio's Research Foundation and by a scholarship from the Eva and Oscar Ahrén's Foundation. We appreciate the skilful experimental assistance of Eva-Lena Forsberg, Agneta Reinholdsson and Alice Skogholm at the Clinical Research Unit, Karolinska University Hospital. Agneta Hilding is gratefully acknowledged for providing the statistical evaluation of the results.

\section{References}

1 Poppit SD, Eckhart JW, McGanogle J, Murgatroyd PR \& Prentice AM. Short-term effect of alcohol consumption on appetite and energy intake. Physiology and Behavior 199960 1063-1070.

2 Westerterp-Plantenga MS \& Verwgen CRT. The appetizing effect of an aperitif in overweight and normal weight humans. American Journal of Clinical Nutrition 199969 205-212.

3 Yeomans MR, Caton S \& Hetherington MM. Alcohol and food intake. Current Opinion in Clinical Nutrition and Metabolic Care 20036 639-644.

4 Wilding JPH. Neuropeptides and appetite control. Diabetic Medicine $200219619-627$.
5 Druce M \& Bloom S. Central regulators of food intake. Current Opinion in Clinical Nutrition and Metabolic Care 20036 361-367.

6 Rohdner-Jeanrenaud E \& Jeanrenaud B. Central nervous system and body weight reduction. Annales d'Endocrinologie $1997 \mathbf{5 8}$ $137-142$.

7 Flood JF \& Morley JE. Increased food intake by neuropeptide Y is due to an increased motivation to eat. Peptides 199112 1329-1332.

8 Rohdner-Jeanrenaud E \& Jeanrenaud B. Obesity, leptin and the brain. New England Journal of Medicine 1996334 324-325.

9 Malmström R, Taskinen M-R, Karonen SL \& Yki-Järvinen H. Insulin increases plasma leptin concentrations in normal subjects and patients with NIDDM. Diabetologia 199639 993-996.

10 Larsson H \& Ahrén B. Short-term dexamethasone treatment increases plasma leptin independently of changes in insulin sensitivity in healthy women. Journal of Clinical Endocrinology and Metabolism 199681 4428-4432.

11 Wabitsch M, Blum W, Muche R, Braun M, Hube F, Rascher W, Heinze E, Teller $\mathrm{W} \&$ Hauner H. Contribution of androgens to the gender difference in leptin production in obese children and adolescents. Journal of Clinical Investigation 1997100 808-813.

12 Fritsche A, Wahl HG, Metzinger E, Renn W, Kellerer M, Haring H \& Stumvoll M. Evidence for inhibition of leptin secretion by catecholamines in man. Experimental and Clinical Endocrinology and Diabetes 1998106 415-418.

13 Röjdmark S, Calissendorff J \& Brismar K. Alcohol ingestion decreases both diurnal and nocturnal secretion of leptin in healthy individuals. Clinical Endocrinology 200155 639-647.

14 Röjdmark S, Rydvald Y, Aquilonius A \& Brismar K. Insulin-like growth factor (IGF-I) and IGF-binding protein-1 concentrations in serum of normal subjects after alcohol ingestion: evidence for decreased IGF-I bioavailability. Clinical Endocrinology 200052 313-318.

15 Calissendorff J, Brismar K \& Röjdmark S. Is increased leptin secretion after acute alcohol ingestion catecholamine-mediated? Alcohol and Alcoholism 200439 281-286.

16 Joannic JL, Oppert JM, Lalou N, Basdevant A, Auboiron S, Raison J, Bornet F \& Guy-Grand B. Plasma leptin and hunger ratings in healthy humans. Appetite $199830129-138$.

17 Romon M, Lebel P, Velly C, Mareaux N, Fruchart JC \& Dallongeville J. Leptin response to carbohydrate or fat meal and association with subsequent satiety and energy intake. American Journal of Physiology 1999277 E855-E861.

18 Date Y, Kojima M, Hosoda H, Sawaguchi A, Mondal MS, Suganuma T, Matsukura S, Kangawa K \& Nakazato M. Ghrelin, a novel growth-hormone releasing acylated peptide, is synthesized in distinct endocrine cell type in the gastro-intestinal tracts of rats and humans. Endocrinology 2000141 4255-4261.

19 Willesen MG, Kristensen P \& Romer J. Co-localization of GH secretagogue receptor and NPY mRNA in the arcuate nucleus of the rat. Neuroendocrinology $1999 \mathbf{7 0} 306-316$.

20 Theodorsson-Norheim E, Hemsén A \& Lundberg JM. Radioimmunoassay for neuropeptide Y (NPY): chromatographic characterization in plasma and tissue extracts. Journal of Clinical and Laboratory Investigation $198545355-365$.

21 Chan JL, Bullen J, Lee JH, Yiannakouris N \& Mantzoros CS. Ghrelin levels are not regulated by recombinant leptin administration and/or three days of fasting in healthy subjects. Journal of Clinical Endocrinology and Metabolism 200489 335-343.

22 Nedvikova J, Krykorkova I, Bartak V, Papezova H, Gold PW, Alesci S \& Pacak K. Loss of meal-induced decrease in plasma ghrelin levels in patients with anorexia nervosa. Journal of Clinical Endocrinology and Metabolism $2003 \mathbf{8 8} 1678-1682$.

23 Flint A, Raben A, Ersboll AK, Holst JJ \& Astrup A. The effect of physiological levels of glucagon-like peptide-1 on appetite, gastric emptying, energy and substrate metabolism in obesity. International Journal of Obesity and Related Metabolic Disorders 200125 781-792.

24 Gutzwiller JP, Drewe J, Hildebrand P, Rossi L, Lauper JZ \& Beglinger C. Effect of intravenous human gastrin-releasing peptide 
on food intake in humans. Gastroenterology $1994 \mathbf{1 0 6}$ 1168-1173.

25 Havel PJ. Peripheral signals conveying metabolic information to the brain: short-term and long-term regulation of food intake and energy homeostasis. Experimental Biology and Medicine $2001226963-977$.

26 Yegen BC, Gurbuz V, Coskun T, Bozkurt A, Kurtel H, Alican I \& Dockray GJ. Inhibitory effects of gastrin releasing peptide on gastric emptying in rats. Regulatory Peptides 199661 175-180.

27 Adrian TE, Ferri GL, Bacarese-Hamilton AJ, Fuessl HS, Polak JM \& Bloom SR. Human distribution and release of a putative new gut hormone, peptide YY. Gastroenterology 198589 1070-1077.

28 Batterham RL, Cowley MA, Small CJ, Herzog H, Cohen MA, Dakin CL, Wren AM, Brynes AE, Low MJ, Ghatei MA \& Cone RD. Gut hormone PYY 3-36 physiologically inhibits food intake. Nature $2002 \mathbf{4 1 8} 650-654$.

29 Arosio M, Ronchi CL, Beck-Peccoz P, Gebbia C, Capiello V, Conte D \& Perrachi M. Effects of modified sham feeding on ghrelin levels in healthy human subjects. Journal of Clinical Endocrinology and Metabolism 200489 5101-5104.
30 Heath RB, Jones R, Frayn KN \& Robertson MD. Vagal stimulation exaggerates the inhibitory ghrelin response to oral fat in humans. Journal of Endocrinology $2004180273-281$.

31 Raben A, Agerholm-Larsen L, Flint A, Holst JJ \& Astrup A. Meals rich with similar energy densities but rich in protein, fat, carbohydrate, or alcohol have different effects on energy expenditure and substrate metabolism but not on appetite and energy intake. American Journal of Clinical Nutrition 200377 91-100.

32 Sibilia V, Rindi G, Pagani F, Rapetti D, Locatelli V, Torsello A, Campanini N, Deghenghi R \& Netti C. Ghrelin protects against ethanol-induced gastric ulcers in rats: studies on the mechanism of action. Endocrinology 2003144 353-359.

33 Konturek PC, Brozozowski T, Pajdo R, Nikiforuk A, Kwiecien S, Harsch I, Drozdowicz D, Hahn EG \& Konturek SJ. Ghrelin - a new gastroprotective factor in gastric mucosa. Journal of Physiology and Pharmacology 200455 325-336.

Received 16 November 2004

Accepted 10 February 2005 